UDC 613.6.027

\title{
ASSESSMENT OF BEHAVIORAL RISK FACTORS OF MEDICAL WORKERS AT MULTIDISCIPLINARY HOSPITAL
}

\author{
E.V. Dubel ${ }^{1}$, T.N. Unguryanu ${ }^{2}$ \\ ${ }^{1}$ BHE VR “Vologda City Hospital №1”, 94 Sovetsky Prospect, Vologda, 160012, Russian Federation \\ ${ }^{2}$ Office the Federal Service for Supervision of Consumer Rights Protection and Human Welfare \\ in the Arkhangelsk region, 24 Gaidara St., Arkhangelsk, 163000, Russian Federation
}

The prevalence of behavioural risk factors among health professionals at the multidisciplinary hospital was the aim of the present research. The study included a questionnaire of the WHO International Programme of Integrated Prevention of Noncommunicable Diseases "Countrywide Integrated Noncommunicable Disease Intervention Programme" (CINDI). The survey involved 333 health professionals: doctors $-14.1 \%$, mid-level and junior medical personnel $-62.2 \%$ and $23.7 \%$, respectively. The average age of the respondents was 42.5 years. The proportion of males and females was $8.4 \%$ and $91.6 \%$, respectively. It was found that a significant proportion of respondents has overweight (34.4\%) and obesity (17.5\%), hypertension (31.1\%). The prevailing part of the hospital medical staff has an average and a high level of physical activity. The eating behaviour of $80 \%$ of health workers is characterized by low consumption of fruit and vegetables. Doctors tend to drink alcohol more frequently than the mid-level and junior medical personnel, at that the consumption of alcohol for the vast majority of persons who participated in the study is moderate. Tobacco consumption is typical for a significant proportion of the respondents (32\%), more common among nurses than among doctors and mid-level medical staff. Health workers of 40-60 years have a high individual risk of coronary heart disease associated with smoking $\left(1.3 \cdot 10^{-4}-1.6 \cdot 10^{-3}\right)$. Persons older than 50 years revealed an unacceptable risk of lung cancer pathology $\left(4.7 \cdot 10^{-4}\right)$, stomach $\left(1.4 \cdot 10^{-4}\right)$, bladder $\left(1.5 \cdot 10^{-4}\right)$, cerebrovascular disease $\left(2.5 \cdot 10^{-4}\right)$ at the effects of smoking.

Key words: health care workers, health risk, risk factors, lifestyle, body mass index, physical activity, dietary habits, alcohol consumption, smoking.

Practical healthcare workers are exposed to many unfavorable factors of their working environment and process, and it leads to higher morbidity levels in this professional group. However, a number of other factors, particularly lifestyle, also have their influence on medical workers' health and well-being [1, 2, 3, 14, 15].

As WHO experts state, lifestyle factors have great influence on various pathologies evolvement. Non-communicable diseases annually cause 38 million deaths all over the world. Most significant behavioral and metabolic factors are: 1) smoking; 2) low physical activity; 3) harmful alcohol use; 4) unhealthy nutrition; 5) hypertension; 6) excess body weight; 7) hypercholesterolemia [4, 5].

Medical workers' commitment to healthsaving behavior not only helps to save labor potential in this professional group but also gives a good and clear example to population. It is medical workers - doctors in particular - who play the key role in popularizing knowledge on healthy lifestyle in our society. But in spite of that behavioral risk factors are widely spread among practical healthcare workers $[1,2,3,10,11,12,13]$.

Research goal was to examine prevalence of behavioral and metabolic risk factors among medical workers of a large multi-field hospital in Vologda and to estimate risk of various organs and systems diseases caused by smoking.

Data and techniques. To obtain information on how greatly medical workers in hospital are exposed to non-communicable diseases risk factors we used WHO «Countrywide Integrated Noncommunicable Disease Intervention Programme» (CINDI) questionnaire [8]. 333 medical workers of Vologodskaya region budgetary health care organization «Vologoskaya city hospital No.1» took part in the interviewing; $14.1 \%$ of them were doctors, $62.2 \%$ were nurses, and $23.7 \%$ were nursing aids. Respondents' average age $(\mathrm{Me})$ was 42.5 years $\left(\mathrm{P}_{25-75}=33-51\right)$. $91.6 \%$ were male and $8.4 \%$ were female.

Risk estimation for various organs and systems diseases caused by smoking was made in

(C) Dubel E.V., Unguryanu T.N., 2016

Dubel Elizaveta Vladislavovna - head of epidemiological department, doctor epidemiologist (e-mail: Elizaveta.dubel@yandex.ru; tel.: +7(8172) 75-70-30).

Unguryanu Tatiana Nikolaevna - Doctor of Medicine, Associate Professor, chief expert of the organization and the operations department (e-mail: unguryanu_tn@mail.ru; tel.: +7 (8182) 21-04-61). 
accordance with "estimation of risk related to lifestyle factors influencing population health" guidelines (2.1.10.0033-11) [9]. Chronic and oncological pathology risk was calculated with the use of "Estimation of population health risk related to lifestyle factors" PC program designed by Federal Scientific Center for Medical and Preventive Health Risk Management Technologies.

We took nicotine content in cigarettes as equal to $0.5 \mathrm{mg}$ and calculated nicotine daily intake into a body. Individual smoking-related risk was calculated with taking the age when a respondent started to smoke and a number of cigarettes he smoked daily into account. Individual risk level within spread of values from $1 \times 10^{-6}$ to $1 \times 10^{-4}$ was considered to be acceptable and higher than $1 \times 10^{-4}$ was thought to be unacceptable (high). We applied risks relation index to find differences between smoking-related disease evolvement risk and disease evolvement risk for non-smokers.
Quantitative data were described with the use of median $(\mathrm{Me})$, percentiles $\left(\mathrm{P}_{25}, \mathrm{P}_{75}\right)$, and risk relation. To give qualitative data we used specific weight and $95 \%$ confidence interval for a share (95\% CI). We tested null-hypothesis about lack of discrepancies between shares with the help of chisquare $\left(\chi^{2}\right)$ criterion and Fisher's exact test. We took $\mathrm{p}<0.05$ as critical value of statistical significance level. Data statistical analysis was performed with STATA 12.1 PC program.

Research results. Having analyzed the obtained data we found out that significant number of medical workers had body mass index beyond the physiological standard limits. More than one third of respondents (34.4\%) have excess body weight and $17.5 \%$ suffer from obesity (picture 1). However we didn't detect any statistically significant differences between various professional categories of hospital staff $\left(\chi^{2}=1.91-\right.$ $4.86, \mathrm{p}=0.088-0.385)$.

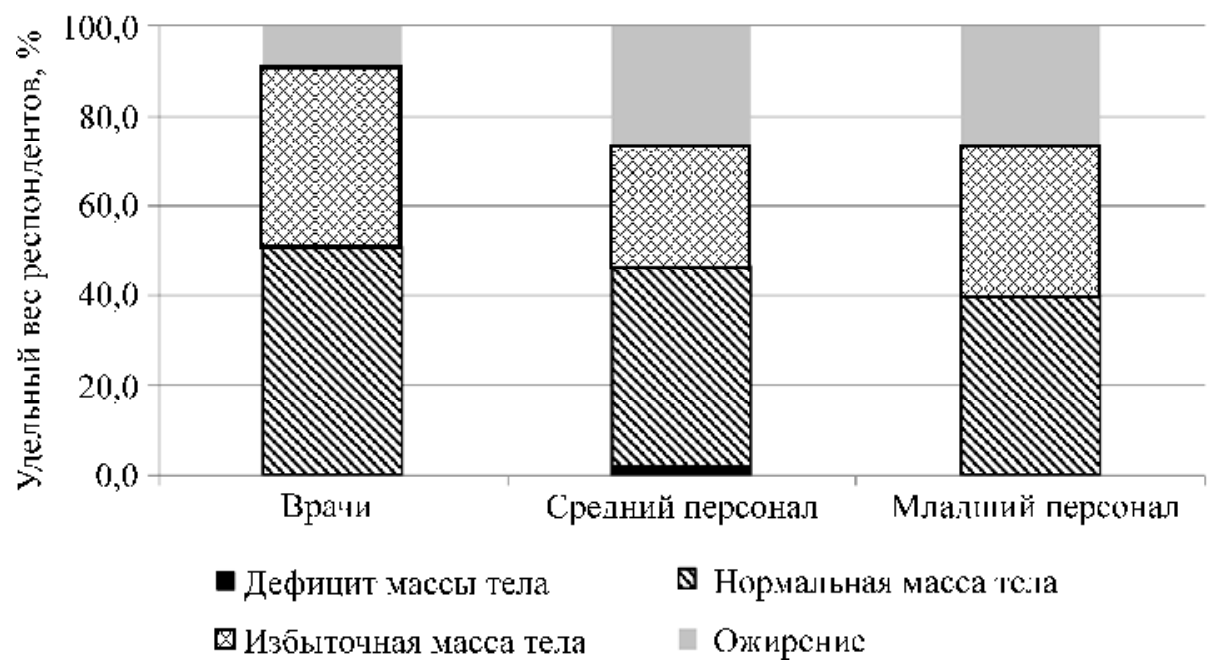

Picture 1 - Prevalence of excess body weight among hospital staff

Y-axis: respondents' specific weight $\mathrm{X}$-axis: doctors - nurses - nursing aids Squares: body mass deficiency; normal body weight; excess body weight; obesity

Specific weight of respondents having high physical activity level amounts to $48.9 \%$ among doctors, $49.7 \%$ among nurses and $45.6 \%$ among nursing aids. $54.4 \%$ of nursing aids, $43.1 \%$ of nurses, and $35.6 \%$ of doctors claim to have moderate level of physical activity. $4.0 \%$ of nurses and $11.1 \%$ of doctors have low level of physical activity in their everyday life. And $4.4 \%$ of doctors as well as $3.0 \%$ of nurses can be called physically inactive. Doctors and nurses tend to have lower levels of physical activity than nursing aids $\left(\chi^{2}=\right.$ $6.41, \mathrm{p}=0.001-0.041)$.
Most medical workers, namely $89.4 \%$ doctors, $91.3 \%$ nurses and $67.5 \%$ nursing aids, know their blood pressure. $39.1 \%$ doctors, $43.9 \%$ nurses and $50.0 \%$ nursing aids received official information on their hypertension from the colleagues. More than $30.0 \%$ of respondents suffer from hypertension. The greatest specific weight of people suffering from arterial hypertension is detected among nursing aids (37.3\%). This parameter is a bit lower among doctors and nurses and amounts to $333 \%$ and $28.7 \%$ correspondingly. At that, $27.7 \%$ doctors, $26.9 \%$ nurses and $32.5 \%$ nursing aids take anti-hypertensive drugs. We did 
not find any statistically significant differences when comparing hypertension prevalence in respondents' groups $\left(\chi^{2}=0.17-1.56, p=0.211-\right.$ $0.676)$.

When analyzing nutrition behavior we determined that most medical workers ate fresh fruit either daily or several times a week. Specific weight of doctors who eat fresh fruit every day amounts to $42.2 \%$ and it is $56.0 \%$ and $40.3 \%$ for nurses and nursing aids correspondingly. 33.3\% doctors, $27.1 \%$ nurses and $29.9 \%$ nursing aids eat fresh fruit several times a week. 56.5\% doctors, $52.9 \%$ nurses and $37.7 \%$ nursing aids eat vegetables (apart from potatoes) every day. 23.9\% doctors, $28.2 \%$ nurses and $25.9 \%$ nursing aids eat such food stuffs several times a week. However, most respondents consume less fresh fruit and vegetables than it is recommended (table 1). Thus, only $17.6 \%$ doctors, $23.7 \%$ nurses and $10.0 \%$ nursing aids eat 400 or more grams of fresh fruit and vegetables every day. For the rest of respondents the amount of fresh fruit and vegetables in their daily ration is insufficient. The share of nurses eating sufficient amount of fruit and vegetables daily is statistically significantly higher than the one of nursing aids $\left(\chi^{2}=4.36, p=\right.$ 0.037).

Table 1

Medical workers distribution according to their nutrition habits

\begin{tabular}{|c|c|c|c|c|c|c|}
\hline \multirow{2}{*}{ Categories } & \multicolumn{2}{|c|}{ Doctors } & \multicolumn{2}{|c|}{ Nurses } & \multicolumn{2}{|c|}{ Nursing aids } \\
\hline & Share, \% & $95 \% \mathrm{CI}$ & Share, \% & $95 \% \mathrm{CI}$ & Share, \% & $95 \% \mathrm{CI}$ \\
\hline \multicolumn{7}{|c|}{$\begin{array}{l}\text { Daily portion of fruit and } \\
\text { vegetables (apart from potatoes): }\end{array}$} \\
\hline & 82.4 & $68.9-95.9$ & 76.3 & $69.5-83.2$ & 90.0 & $81.4-98.6$ \\
\hline$>400 \mathrm{gr} /$ day & 17.6 & $4.1-31.1$ & 23.7 & $16.8-30.5$ & 10.0 & $1.4-18.6$ \\
\hline \multicolumn{7}{|c|}{ Fat type used for sandwiches: } \\
\hline Nothing & 44.7 & $29.9-59.4$ & 28.2 & $21.9-34.3$ & 23.4 & $13.7-33.0$ \\
\hline Margarine & 0.0 & - & 1.8 & $0.1-3.8$ & 3.7 & $8.3^{*}$ \\
\hline Butter & 46.7 & $31.9-61.6$ & 65.0 & $58.5-71.6$ & 67.5 & $56.8-78.2$ \\
\hline Lard & 0.0 & - & 1.5 & $3.1 *$ & 2.6 & $6.2 *$ \\
\hline \multirow{2}{*}{\multicolumn{7}{|c|}{$\begin{array}{l}\text { Fat content in consumed dairy } \\
\text { products: } \\
>3,2 \%\end{array}$}} \\
\hline & 21.3 & $9.1-33.4$ & 15.5 & $10.5-20.4$ & 20.0 & $10.7-29.3$ \\
\hline$<3,2 \%$ & 46.8 & $31.9-61.6$ & 61.4 & $54.7-68.0$ & 54.7 & $43.1-66.2$ \\
\hline Do not consume & 23.4 & $10.8-35.9$ & 15.5 & $10.5-20.4$ & 16.0 & $7.5-24.5$ \\
\hline \multicolumn{7}{|l|}{ Excess salt use: } \\
\hline Never & 38.3 & $23.8-52.7$ & 28.2 & $21.9-34.3$ & 22.4 & $12.8-31.9$ \\
\hline Sometimes & 51.1 & $36.2-65.9$ & 65.5 & $58.9-72.1$ & 75.0 & $65.0-84.9$ \\
\hline Always & 4.3 & 10.2 & 4.9 & $1.9-7.8$ & 0 & - \\
\hline
\end{tabular}

N o t e : * - Only top limit of $95 \% \mathrm{CI}$ is given; bottom limit is not calculated as the condition of $95 \%$ CI calculation for a share cannot be fulfilled.

As we analyzed alcohol use by medical workers we found out that $82.9 \%$ doctors, $87.8 \%$ nurses and $85.7 \%$ nursing aids drank alcohol with various frequency $\left(\chi^{2}=0.08-0.78 ; p=0.376-0.779\right)$ (table 2).

$2.2 \%$ nurses and $1.5 \%$ nursing aids admitted drinking alcohol every day; $31.6 \%$ doctors, $8.8 \%$ nurses and $4.4 \%$ nursing aids did it weekly. $42.1 \%$ doctors, $43.9 \%$ nurses and $30.9 \%$ nursing aids said they drank alcohol once or several times a month. Doctors and nurses drink alcohol statistically significantly more frequently than nursing aids $\left(\chi^{2}=\right.$ $17.43-20.69, \mathrm{p}=<0.001-0.006)$.
Most respondents drank considerable amount of alcohol at a time less frequently than once a month; such habit was characteristic for $33.3 \%$ nursing aids, $32.2 \%$ nurses and $31.6 \%$ doctors. Average volume of beer (Me) drunk by interviewed medical workers at a time amounted to $500 \mathrm{ml}$, and non-fortified wines, $200 \mathrm{ml}$. Volume of fortified wines (Me) drunk at a time was $200 \mathrm{ml}, 150 \mathrm{ml}$ and $100 \mathrm{ml}$ for doctors, nurses and nursing aids correspondingly; as for strong spirits, the volume was $150 \mathrm{ml}, 100 \mathrm{ml}$ and $100 \mathrm{ml}$ for the same groups correspondingly. Average absolute alcohol consumption is higher among doctors $(22.3$ gr) than among both nurses (13.1 gr) and nursing aids (10.7 gr).

Description of alcohol use by medical workers 


\begin{tabular}{|c|c|c|c|c|c|c|}
\hline \multirow{2}{*}{ Categories } & \multicolumn{2}{|c|}{ Doctors (1) } & \multicolumn{2}{|c|}{ Nurses (2) } & \multicolumn{2}{|c|}{ Nursing aids (3) } \\
\hline & Share, $\%$ & $95 \% \mathrm{CI}$ & Share, $\%$ & $95 \% \mathrm{CI}$ & Share, $\%$ & $95 \% \mathrm{CI}$ \\
\hline \\
\hline Drink alcohol & 26.7 & $13.2-40.1$ & 25.2 & $19.2-31.3$ & 53.3 & $41.8-64.9$ \\
\hline Do not drink alcohol & 73.3 & $59.9-86.8$ & 74.8 & $68.7-80.8$ & 46.7 & $35.1-58.2$ \\
\hline \multirow{2}{*}{\multicolumn{7}{|c|}{$\begin{array}{l}\text { Alcohol use frequency: } \\
\text { Once or several times a week }\end{array}$}} \\
\hline & 31.6 & $16.1-47.1$ & 11.0 & $6.4-15.6$ & 5.9 & $0.1-11.6$ \\
\hline Once or several times a month & 42.1 & $25.7-48.6$ & 43.9 & $36.7-51.2$ & 30.9 & $19.6-42.1$ \\
\hline Once or several times a year & 18.4 & $5.5-31.3$ & 28.6 & $21.9-35.2$ & 22.1 & $11.9-32.2$ \\
\hline
\end{tabular}

$20.2 \%$ medical workers smoke every day; $11.8 \%$ do it periodically, and $28.8 \%$ respondents have never smoked. Specific weight of medical workers - tobacco smokers - amounts to $26.7 \%$, $25.2 \%$ and $53.3 \%$ of doctors, nurses and nursing aids correspondingly (table 3 ). Specific weight of smoking nursing aids is statistically significantly higher than those of doctors and nurses $\left(\chi^{2}=8.15-\right.$ $19.56, p=<0.001-0.004)$.

Table 3

Description of smoking habits among medical workers

\begin{tabular}{|l|c|c|c|c|}
\hline \multicolumn{1}{|c|}{ Smoking peculiarities } & measures, units & doctors & nurses & nursing aids \\
\hline Smokers' specific weight & $\begin{array}{c}\% \\
(95 \% \mathrm{CI})\end{array}$ & $\begin{array}{c}26.7 \\
(13.2-40.1)\end{array}$ & $\begin{array}{c}25.2 \\
(19.2-31.3)\end{array}$ & $\begin{array}{c}53.3 \\
(41.8-64.9)\end{array}$ \\
\hline Non-smokers' specific weight & $\%$ & 73.3 & 74.8 & 46.7 \\
& $(95 \% \mathrm{CI})$ & $(59.9-86.8)$ & $(68.7-80.8)$ & $(35.1-58.2)$ \\
\hline $\begin{array}{l}\text { Average age when started } \\
\text { smoking }\end{array}$ & $M e\left(P_{25-75}\right)$ & $\begin{array}{c}21 \\
(18-29)\end{array}$ & $(17-26)$ & $(16-26)$ \\
\hline Age when started smoking & $M e\left(P_{25-75}\right)$ & 21 & 20 & 18 \\
& & $(18-29)$ & $(17-26)$ & $20(17-26)$ \\
\hline Length of smoking & $M e\left(P_{25-75}\right)$ & $10(9-20)$ & $15(10-20)$ & $15(6-20)$ \\
\hline Number of cigarettes per day & $M e\left(P_{25-75}\right)$ & $20(10-20)$ & $15(6-20)$ & 15 \\
\hline Pack/per year index & - & 10.0 & 11.3 & \\
\hline
\end{tabular}

Age when doctors started smoking (Me) is 21 , nurses, 20, and nursing aids, 18 . The greatest length of smoking is characteristic for nursing aids (20 years); as for doctors and nurses, this parameter is 15 years and 10 years correspondingly. On average doctors tend to smoke more cigarettes a day $(\mathrm{Me}=$ $20)$ in comparison with nurses $(\mathrm{Me}=15)$ and nursing aids $(\mathrm{Me}=15)$. And a share of respondents willing to give up smoking is bigger among nursing aids $(65.0 \%)$ than doctors $(58.3 \%)$ and nurses $(53.1 \%)$. Specific weight of those unwilling to stop smoking amounts to $12.5 \%, 33.3 \%$ and $20.4 \%$ among these professional groups correspondingly.
Smoking leads to increased individual risk of ischemic heart disease, cerebrum vessels disease, and aortic aneurism; this risk is $1.1-1.2$ times higher for smokers among respondents aged 20-29 and $1.1-1.5$ times higher among respondents aged 30-39. As for age groups 40-49 and 50-60, the risk ratio for them is 1.3-1.9 and 1.8-2.7 correspondingly. And we should note that ischemic heart disease risk caused by smoking is unacceptable among medical workers in these age groups. Cerebrum vessels disease risk is high for smoking respondents aged 50-60 (picture 2). 


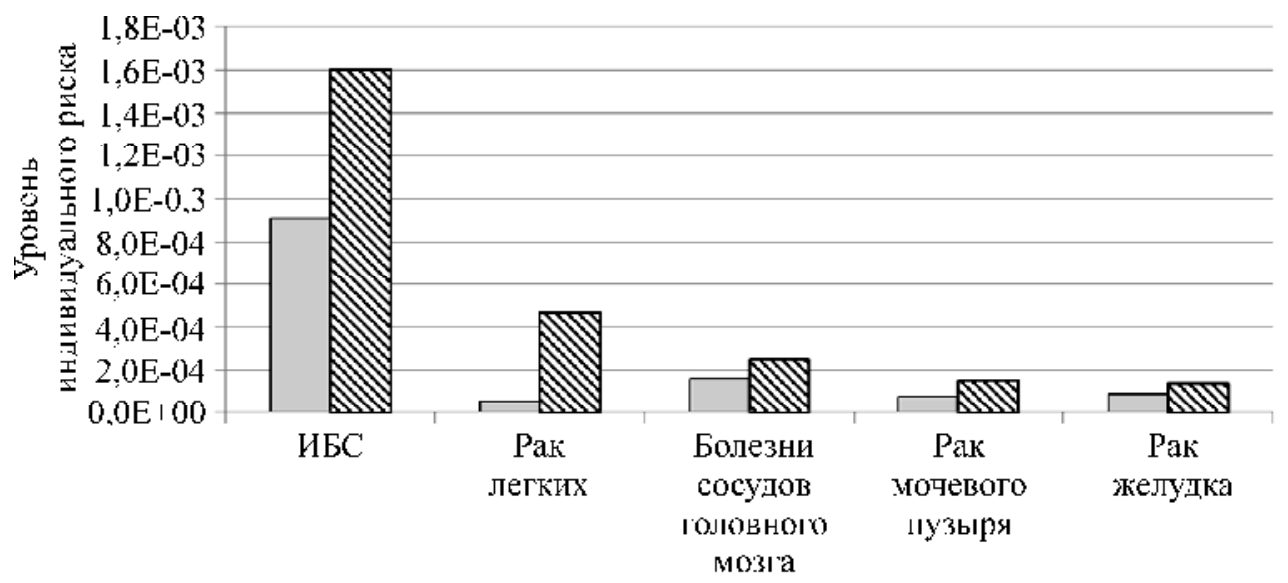

$\square$ ІІекуряшие респолдетты \$ Куряшис реснонцснты

Picture 2 Individual risk level for smoking and non-smoking medical workers aged 50-60

Vertical axis: Individual risk level: horizontal axis: ischemic heart disease; lung cancer; cerebrum vessels diseases; urinary bladder cancer; stomach cancer

Below - non-smoking respondents and smoking respondents

The older smokers are the higher individual risk they run in respect of such diseases as chronic bronchitis and lung emphysema. Thus, risk ratio among respondents younger than 30 amounts to 1.9; if we take 30-39, 40-49 and 50-60 smokers' age groups we can see that they run $3.8,4.6$ and 8.8 times higher risk of chronic respiratory pathology evolvement in comparison with non-smokers.

Individual risk of lung cancer caused by smoking amounts to $4.7 \times 10^{-4}$ among medical workers aged $50-60$ and this risk level is unacceptable. As for younger respondents they run rather acceptable risk of this pathology. But still lung cancer risk for smoking respondents aged 2029 is 2.1 times higher than for non-smokers of the same age; we detected 3.3 and 4.2 higher lung cancer risks in 30-39 and 40-49 age groups correspondingly.

Smoking medical workers aged 50-60 also have rather high risk of stomach cancer evolvement $\left(1.4 \times 10^{-4}\right)$. Individual risk level for other oncologic pathologies evolving in digestive system (including oral cavity, esophagus, and pancreas cancer) as a result of smoking is acceptable among respondents of all age groups as it does not exceed $2.2 \times 10^{-5}$. Urinary bladder cancer risk caused by smoking is acceptable in 20-29 age group $\left(2.8 \times 10^{-6}\right), 30-39$ age group $\left(7.9 \times 10^{-6}\right)$, and $40-49$ age group $\left(2.4 \times 10^{-5}\right)$; it is rather high for respondents aged 50-60 $\left(1.5 \times 10^{-4}\right)$.

When analyzing the received data we took daily quantity of absolute alcohol intake as being less than 30 grams for each age group. Given such quantities, individual risk of any pathology caused by alcohol equals to background value. Therefore, we did not evaluate individual risks of any alcoholcaused pathology.

To sum up, we can state that excess body weight, obesity, and increased blood pressure are widely spread factors causing chronic noncommunicable diseases among medical workers of a multi-field hospital. Most medical workers have moderate and high level of physical activity. Most respondents admitted non-rational nutrition; daily consumption of fresh fruit and vegetables amounts to less than 400 grams for most medical workers. Doctors tend to drink alcohol more often than other categories of medical staff; still we note that alcohol consumption is quite moderate for the most respondents. Smoking is characteristic for a great share of respondents and is more widely spread among nursing aids than among doctors and nurses.

Smoking leads to much higher individual risk of chronic and oncologic respiratory pathology among medical workers. Smoking respondents aged 50-60 run unacceptable level of lung cancer, stomach cancer, urinary bladder cancer, and cerebrum vessels diseases. Individual risk of ischemic heart disease caused by smoking is high among respondents aged 40 and older. Risk of pathologies caused by alcohol equals to background value. 


\section{References}

1. Bektasova M.V., Kaptsov V.A., Sheparev A.A. Social'no-gigienicheskoe issledovanie zabolevaemosti, obraza zhizni, uslovij truda medicinskogo personala lechebnyh uchrezhdenij na primere Primorskogo kraja [Sociohygienic study of incidence, lifestyle and working conditions of medical institutions personnel in the context of Primorsky krai]. Put' nauki, 2014, no. 6, pp. 109-111. (in Russian).

2. Boiko I.B., Sashin A.V. O sostojanii zdorov'ja medicinskih rabotnikov RF [About the state of health of medical staff of the Russian Federation]. Rossiiskii mediko-biologicheskii vestnik imeni akademika I. P. Pavlova, 2008, no. 3, pp. 40-47. (in Russian).

3. Guryanov M.S. Obraz i uslovija zhizni medicinskih rabotnikov [Way and conditions of living among the medical personals]. Vestnik RUD. Serija: Medicina, 2009, no. 4, pp. 507-510. (in Russian).

4. Doklad o situacii v oblasti neinfekcionnyh zabolevanij v mire, $2010 \mathrm{~g}$. [Global status report on noncommunicable diseases, 2010]. Vsemirnaja organizacija zdravoohranenija, 2013. Available at: http://apps.who.int/ iris/bitstream/10665/44579/6/9789244564226_rus.pdf (01.03.2016).

5. Doklad o situacii $\mathrm{v}$ oblasti neinfekcionnyh zabolevanij $\mathrm{v}$ mire, $2014 \mathrm{~g}$. [Global status report on noncommunicable diseases, 2014]. Vsemirnaja organizacija zdravoohranenija, 2014. Available at: http://www.who.int/nmh/publications/ncd-status-report-2014/ru (01.03.2016).

6. Karaseva T.V., Ruzhenskaja E.V. Osobennosti motivacii vedenija zdorovogo obraza zhizni [The characteristics of motivation to follow healthy life-style]. Problemy social'noj gigieny, zdravoohranenija $i$ istorii mediciny, 2013, no. 5, pp. 23-24. (in Russian).

7. Levina T.V., Krasnova Ju.N. Jepidemiologija tabakokurenija [Epidemiology of tobacco smoking]. Sibirskij medicinskij zhurnal, 2013, 6, pp. 5-8. (in Russian).

8. Monitorirovanie povedencheskih faktorov riska neinfekcionnyh zabolevanij sredi naselenija: rukovodstvo [Monitoring of behavioral risk factors for non-communicable diseases among the population: guide]. Moscow: MAKS Press, 2004, 54 p. (in Russian).

9. MR 2.1.10.0033-11 Ocenka riska, svjazannogo s vozdejstviem faktorov obraza zhizni na zdorov'e naselenija: metodicheskie rekomendacii [Evaluation of the risk associated with the impact of lifestyle factors on the population health: guidelines]. Available at: http://www.consultant.ru (16.10.2015).

10. Bourne P.A., Lilleth G. V, Hazel L., Maureen K.-C.D. Health, lifestyle and health care utilization among health professionals. Medicine \& Healthcare, 2010, no. 6, pp. 557-565.

11. Joos L., Glazemakers I., Dom G. Alcohol Use and Hazardous Drinking among Medical Specialists. European Addiction Research, 2013, no. 2. Available at: https://www.karger.com/Article/Abstract/341993 (16.01.2016).

12. Josseran L. French physicians smoking behavior. Abstract of the 11th Conference on Tobacco or Health. Chicago, USA, 6-11 August, 2000, pp.101.

13. Mony P.K., Vishwanath N.S., Krishnan S. Tobacco use, attitudes and cessation practices among healthcare workers of a city health department in Southern India. Journal of family medicine and primary care, 2015, no. 2, pp. 261-264.

14. Occupation health of Health Care Workers, 2010. Available at: http://www.ttl.fi/en/publications/Electronic_publications/Documents/occupational_health_of_health_care_workers.pdf (15.01.2016).

15. Wiskow C., Albreht T., Pietro C. De How to create an attractive and supportive working environment for health professionals. Health systems and policy analysis, 2010, no.15, pp. 1-48.

Dubel E.V., Unguryanu T.N. Assessment of behavioral risk factors of medical workers at multidisciplinary hospital. Health Risk Analysis, 2016, no. 2, pp. 60-67. 